\title{
Investment and exchange rate uncertainty
}

\author{
Vincenzo Atella ${ }^{a}$, Gianfranco Enrico Atzeni ${ }^{b, *}$, \\ Pier Luigi Belvisi ${ }^{\mathrm{c}}$ \\ ${ }^{a}$ CEIS Tor Vergata, University of Rome "Tor Vergata”, Rome, Italy \\ ${ }^{\mathrm{b}}$ Dipartimento di Economia Istituzioni e Società, University of Sassari and CRENoS, \\ Viale Regina Margherita 15, 07100 Sassari, Italy \\ c University of Rome "Tor Vergata", Rome, Italy
}

\begin{abstract}
The literature on the relationship between exchange rate and investment mainly focuses on the devaluation argument, which provides evidence that a devaluation may positively affect investment spending. The goal of this paper is to extend the analysis to how exchange rate variability can influence firm innovation process. Employing a large panel of Italian firms and using a model of signal extraction we find that exchange rate volatility reduces investment, with a decreasing sensitivity the greater the firm market power. A stable exchange rate is then an incentive to invest as it allows a more reliable estimation of its marginal productivity. To this extent, any economic system may benefit from a stable exchange rate in terms of investment and profit, provided it is able to strengthen its firm market power. (C) 2003 Society for Policy Modeling. Published by Elsevier Inc. All rights reserved.
\end{abstract}

JEL classification: D81; E22; F41; F42

Keywords: Exchange rate; Firm heterogeneity; Investment; Uncertainty

\section{Introduction}

Since the move to a fixed exchange rate, in many European countries the discussion about exchange rate stability has assumed new outlines with respect to the typical devaluation argument. Firms, especially those in traditional sectors,

\footnotetext{
* Corresponding author. Tel.: +39-079-228939.

E-mail address: atzeni@uniss.it (G.E. Atzeni).
} 
used to rely on devaluation in order to offset the reduction of competitiveness on international markets. At least in the short run, through a temporary gain in competitiveness, a devaluation may drive production up. However, the effects on investment decisions, which are typically irreversible, need to be analysed considering a longer time horizon. Exchange rate strength and stability push firms to invest in innovation, not only to increase price competitiveness, but also to gain a more general ability to compete in the market. According to this view, firms should move to the most valuable part of the market, driven by the type of technology employed and by their level of competition (Onida, 1986).

It is widely recognised that technological leadership and firm growth are closely related to investment capacity. At the same time, countries that showed a larger quantity and higher quality of investment spending, with technological leadership, such as Germany, Japan and United States, had a strong and stable currency for a long period of time. As long as the Euro will represent a stable currency, we should expect that other European countries can experience a similar behaviour, thus having beneficial effects on investment demand and on growth. The question for us is then to understand the consequences of a strong and stable exchange rate on firms behaviour, rather than those of a devaluation.

Most of the literature on the relationship between exchange rate and investment mainly focuses on the devaluation argument, which provide evidence that a devaluation may positively affect investment spending. In this literature, such a relationship has been often analysed with models which emphasise the distinction according to the degree of sectors' exposition to international competition. Its main limit relies on the degree of aggregation at sector level, which prevents an analysis of the impact of firms heterogeneity on investment behaviour. ${ }^{1}$ Any analysis which takes into account this issue should consider firm heterogeneity and its behaviour in international markets. In fact, the more the firm is price taker in the domestic and foreign market the less will be its ability to offset changes due to exchange rate. Our view is that exchange rate stability, rather than its level, affects investment decisions, because different types of firms show a different exchange rate sensitivity through the profit channel.

As shown in Atella, Atzeni, and Belvisi (2003), devaluation plays an important role in explaining firms' investment behaviour through the profit channel. In particular, it has emphasised the role of the different degree of firm external exposure, via imported inputs and revenues from exports. From estimation of the long run elasticities of investment with respect to exchange rate (Atella et al., 2003, Table 2), they found that firms more export oriented, with a higher mark up, a greater share of innovative investment, a low foreign exposure of costs, a higher

\footnotetext{
${ }^{1}$ An example of this literature is represented by the contribution of Campa and Goldberg (1999, 1995). See also Goldberg (1993) for a survey on this topic. Regarding Italy, to our knowledge there exist two empirical investigations. In the first one (Paganetto, 1995) sectorial data are employed, while in the second one (Nucci \& Pozzolo, 2001) firm level data are used. Both papers conclude saying that an exchange rate devaluation leads to an increase in investment spending.
} 
R\&D intensity, and those supplying differentiated goods are less sensitive to exchange rate variations. For these groups, investment decisions are weakly related to short run increment of competitiveness due to exchange rate.

The goal of the paper is to investigate the effects of exchange rate uncertainty on investment demand, which is definitely dependent on firm specific characteristics, such as type of industry, size, export propensity and market power.

In Section 1 we develop a simple model which takes into account the effect of exchange rate volatility on expected profit. A greater exchange-rate-induced profit variability may reduce the optimal stock of capital in any period through the profit channel, depending on firm foreign exposure and market power. According to our findings, in a longer time horizon, exchange rate volatility plays a major role in describing investment demand, with stability of exchange rate associated with a higher level of investment. In Section 2, starting from the results of our empirical analysis, we draw some policy implications. In the concluding remarks we stress the idea that the effect of exchange rate variability on investment is strictly linked to the degree of monopoly power, and is dependent on the type of sector.

\section{Exchange rate volatility, expected profits and market power: a model with signal extraction problems}

From a theoretical point of view, a volatile exchange rate can offer profit opportunities to export oriented firms, provided that they behave like risk neutral agents. However, for irreversible decisions, such as investment spending, and given risk neutrality, a greater profit volatility may reduce the optimal (desired) stock of capital in any period, depending on firm foreign exposure. ${ }^{2}$

As shown in Atella et al. (2003), firms with greater market power can offset the negative effects of a volatile exchange rate. A firm with either a low domestic market power or acting in a more competitive international market, has to face a higher degree of uncertainty, given that exchange rate shocks limit firm ability to estimate the present value of future profit streams.

A model that wants to explain these behaviours should link investment to expected profits, assigning a role to exchange rate expectations. A model in which firms perceive exchange rate variation as permanent, as for instance in Nucci and Pozzolo (2001), it is not satisfactory. Accordingly, we need to investigate how

\footnotetext{
${ }^{2}$ Hayashi (1982) underlines that, given profit defined as $\pi_{t}=\left[p_{t} F\left(K_{t}, N_{t}\right)-w_{t} N_{t}\right]$, where $p$ is the firm output price, $F$ is the production function, $K$ is the capital stock, $N$ is the vector of inputs and $w$ the vector of input prices, maximising the present value of firms, under the capital accumulation constraint with adjustment costs, we obtain the identity between marginal benefits and marginal costs of a unit of capital. In this way, we may define the optimal path of investment. Given the cost of an additional unit of capital, changes in the marginal benefits, due to variation of profit following the exchange rate fluctuation, cause deviations from the optimal investment path. The exchange rate, as it influences both $p$ and $w$, will have an effect on investment which depends on the degree of foreign exposure of cost and revenues.
} 
expectations take form, to take into account the uncertainty about future profit due to exchange rate and the reduction of firm growth capability.

\subsection{The model}

Recently, Darby, Hallet, Ireland, and Piscitelli (1999), employing the Dixit and Pindyck (1994) model, show that exchange rate volatility may reduce investment. As a consequence of their framework, i.e., considering the invest-wait-do-not-invest decisions, they calculate the threshold values under which exchange rate variability reduces investment. The necessary conditions for investment to fall, as exchange rate volatility increases, depends directly on exchange rate volatility and inversely on the opportunity cost of waiting. The estimation carried out is, however, only loosely related to the model (Darby et al., 1999).

In our attempt to find some evidence of the impact of exchange rate uncertainty on investment, we prefer to shed light on the uncertainty-expected profits relation, and to derive a simple testable model. Our hypothesis is that profit volatility influences the marginal benefit of an additional unit of capital, and this source of uncertainty may cause unexpected change in the optimal investment path. We model this approach employing the Lucas (1973) framework of optimal decisions under signal extraction problems, where profit volatility affects investment decisions.

Expected profit for a firm selling in the domestic and in the foreign market depends on the domestic and the foreign price of the firm's goods and its imported inputs. Although the signal extraction problem is generally related to prices, here it will be referred to profit. In fact, exchange rate variability affecting input and output foreign prices, makes total profit (foreign and domestic) more volatile. However, while in the original Lucas framework agents cannot distinguish the source of variability, in this model we assume that firms can distinguish between the domestic and the foreign source of price variations. The signal extraction problem arises when, evaluating the present value of the volatile flow of foreign profits, firms are not able to precisely forecast the exchange rate pattern.

If, for simplicity, we neglect the labour market from our analysis (which should not be directly influenced by exchange rate), ${ }^{3}$ expected profit can be modelled as:

$$
E_{t}\left(\pi_{t}\right)=E_{t}\left(p_{t}\right) q_{t}-E_{t}\left(p_{t}^{\text {in }}\right) q_{t}^{\text {in }}-w_{t} L_{t},
$$

where $p$ and $q$ are the goods prices and quantities, $w$ is wage, $L$ is total work force and $p^{\text {in }}$ and $q^{\text {in }}$ denote input prices and quantities, respectively. By splitting both good and input prices into the domestic and the foreign component we can rewrite $p_{t}$ as:

$$
p_{t}=(1-\delta) p_{t, \mathrm{D}}+\delta p_{t, \mathrm{~F}}=(1-\phi) p_{t, \mathrm{D}}+\phi\left(\frac{p_{t, \mathrm{D}}}{\operatorname{rex}_{t}}\right)
$$

\footnotetext{
${ }^{3}$ Actually, recent studies show that exchange rate have significant wage and employment implications (Goldberg \& Tracy, 1999).
} 
where $\delta$ represents the share of export, while the D and F subscripts denote respectively the domestic and the foreign price. Similarly, for the input prices we will have:

$$
p_{t}^{\text {in }}=(1-\phi) p_{t, \mathrm{D}}^{\text {in }}+\phi\left(\frac{p_{t, \mathrm{D}}^{\text {in }}}{\operatorname{rex}_{t}}\right)
$$

Following Lucas (1973) we assume that the expected price is a weighted average of the two components:

$$
\begin{aligned}
E_{t}\left(p_{t}\right) & =(1-\delta)(1-\theta) p_{t, \mathrm{D}}+\delta \theta E_{t-1}\left(p_{t, \mathrm{~F}}\right) \\
& =(1-\delta)(1-\theta) p_{t, \mathrm{D}}\left(1+\frac{\delta \theta}{E_{t-1}\left(\operatorname{rex}_{t}\right)}\right)
\end{aligned}
$$

where $\theta=\sigma_{\mathrm{e}}^{2} /\left(\sigma_{\mathrm{p}}^{2}+\sigma_{\mathrm{e}}^{2}\right)$ is the weight, $\sigma_{\mathrm{e}}^{2}$ represents the variance of exchange rate, $\sigma_{\mathrm{p}}^{2}$ the variance of the price expressed in the domestic currency and $E$ is the expectation operator. If $\sigma_{\mathrm{e}}^{2}$ is relatively large with respect to $\sigma_{\mathrm{p}}^{2}$, then a signal extraction problem arises, as profits show a volatility mainly due to the volatility of exchange rate. The greater is the firm foreign exposure of cost and revenues, the more unpredictable are profits. The same argument applies to the price of imported inputs. Through these channels, exchange rate volatility determines the uncertainty on expected profit, but the extent and the implication of this relationship remain an empirical question.

\subsection{Empirical results}

Exchange rate variability may affects export revenues and imported input costs differently. In Table 1, the variability of foreign exposure of cost and revenues is displayed. Data in our sample show that revenues are more volatile than costs, considering both time series and the cross section average. Thus, we need to verify the existence of a different impact of exchange rate volatility on profit depending on firms specific characteristics, and in particular on their market power. In Appendix B we report the estimation of the impact of exchange rate variability on profit, split in revenue and cost channels.

Table 1

Foreign exposure of costs and revenues: standard deviation

\begin{tabular}{lll}
\hline Years & Foreign exposure of costs, $\phi$ & Foreign exposure of revenues, $\delta$ \\
\hline 1990 & 0.0108 & 0.0160 \\
1991 & 0.0019 & 0.0029 \\
1992 & 0.0026 & 0.0039 \\
1993 & 0.0237 & 0.0352 \\
1994 & 0.0047 & 0.0070 \\
Cross-section average & 0.0178 & 0.0286 \\
\hline
\end{tabular}


Having found evidence of the reduction of profits associated to exchange rate variability, ${ }^{4}$ we introduce the exchange rate variability (SIGMA) as a variable in a dynamic ECM specification. This variable is split according to foreign exposure of costs $(\phi)$ and revenues $(\delta)$. In its most general specification, the estimated model is:

$$
\begin{aligned}
\Delta I_{i, t}= & \beta_{0}+\beta_{1} \Delta V_{i, t}+\beta_{2} \Delta \text { PROFIT }_{i, t}+\beta_{3} \Delta \mathrm{UC}_{i, t}+\beta_{4} \Delta \mathrm{REX}_{t} \\
& +\beta_{5} I_{i, t-1}+\beta_{6} V_{i, t-1}+\beta_{7} \mathrm{REX}_{t-1}+\beta_{8} \mathrm{SIGMA}_{t-1} \delta_{i} \\
& +\beta_{9} \mathrm{SIGMA}_{t-1} \phi_{i}
\end{aligned}
$$

where $I$ is investment, $V$ represents output, PROFIT is profits, $\mathrm{UC}$ is the user cost of capital and REX is the real exchange rate. ${ }^{5}$ In Eq. (5) variables are expressed as growth rates $(\Delta)$ or as levels in logs (Table 2).

Estimation results from Eq. (5) are reported in Tables 3 and 4. The first finding is that an increase of exchange rate volatility reduces investment spending through the profit channel. This supports the idea that profit variability depresses investment. Moreover, we would expect that exchange rate volatility has a different impact depending on the firm's sector and market power. More specifically, SIGMA should be less important for those firms with market power, as these are able to cushion increases in the exchange rate variability, i.e., greater uncertainty on the 'imported' costs and 'exported' revenues, with a higher mark up. ${ }^{6}$

In order to account for sector heterogeneity and firm's market power, we estimate Eq. (5) on four sub samples, obtained by grouping firms according to the Pavitt firm classification. To understand the role played by market power, we introduce slope and intercept dummies variables for firms with low and high mark up. The results are displayed in Table 4. Exchange rate variability, which is split according to foreign exposure of costs and revenues, is negative and significant for the supplier-dominated sectors (Pavitt 1), for the specialised suppliers sectors (Pavitt 2) and the for the scale-intensive sectors (Pavitt 3). On the contrary, exchange rate and its variability are not significant for the science-based sector (Pavitt 4). This is an important result, as we expect that R\&D intensive firms are less sensitive to exchange rate fluctuations when choosing their optimal investment path. The evidence suggests that the effect of variability on the cost side falls about 53\% from Pavitt 1 to Pavitt 2, while it is similar for firms in Pavitt 2 and Pavitt 3. On the revenues side, the effect slides down to about $62 \%$ from Pavitt 1 to Pavitt 2 and rises by about $40 \%$ from the latter to Pavitt 3 .

It is of some interest to consider that for the supplier-dominated sector the sensitivity trough imported cost is much higher than trough export revenues, while this gap is smaller in the specialised-supplier sector and in the scale intensive sector.

\footnotetext{
${ }^{4}$ See Appendix B and Table 2 for the results.

${ }^{5}$ See Appendix A for the details about the calculation of the variables.

${ }^{6}$ From the financial point of view, firms with a higher mark-up can rely on greater cash flows and thus they are less constrained in financing their investments.
} 
Table 2

Exchange rate variability and profits

\begin{tabular}{|c|c|c|c|c|c|c|c|c|c|c|}
\hline \multicolumn{11}{|c|}{ Whole sample (2988 firms) $-(1989-1994)^{a}$} \\
\hline $\operatorname{PROFIT}_{t-1}$ & rex & SIGMA & SIGMA $\delta$ & SIGMA. $\phi$ & $\begin{array}{l}\text { Dummy } \\
\text { high } \\
\text { markup }\end{array}$ & $\begin{array}{l}\text { Dummy } \\
\text { low } \\
\text { markup }\end{array}$ & $\begin{array}{l}\text { Slope } \\
\text { dummy } \\
\text { SIGMA. } \delta\end{array}$ & $\begin{array}{l}\text { Slope } \\
\text { dummy } \\
\text { SIGMA. } \phi\end{array}$ & Adj. $R^{2}$ & DW \\
\hline $0.912(766.8)$ & $-1.517(-59.70)$ & $-0.011(-3.93)$ & & & & & & & .33 & 2.48 \\
\hline $0.903(1,069)$ & $-1.781(-73.77)$ & & $0.064(7.60)$ & $-0.048(-4.14)$ & & & & & .31 & 2.47 \\
\hline $0.924(398.8)$ & $-1.091(-24.6)$ & & & & $-0.083(-13.54)$ & & $0.094(8.40)$ & $-0.002(-0.13)$ & .32 & 2.50 \\
\hline $0.928(349.48)$ & $-1.112(-24.81)$ & & & & & $-0.097(-16.43)$ & $0.130(11.78)$ & $0.039(2.45)$ & .32 & 2.50 \\
\hline
\end{tabular}

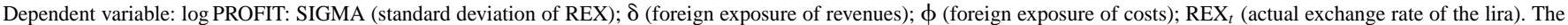
actual estimation period is 1990-1994, due to the lags and first differences in the variables. All regressors are in logs. The threshold value for dummy high-low markup is 55\%.

a GLS estimation method for 6 years. Student's $t$ is reported within the parenthesis. 
Table 3

Estimates of the dynamic investment model (ECM) with exchange rate variability

\begin{tabular}{|c|c|c|c|c|c|c|c|c|c|c|}
\hline Whole sample (29 & 8 firms $)-($ & $89-1994)^{\mathrm{a}}$ & & & & & & & & \\
\hline INTP & $\Delta V$ & $\triangle$ PROFIT & $\Delta \mathrm{UC}$ & $\triangle \mathrm{REX}$ & $V_{t-1}$ & $\operatorname{REX}_{t-1}$ & $I_{t-1}$ & SIGMA & Adj. $R^{2}$ & DW \\
\hline$-2.372(-104.1)$ & $1.00(88.8)$ & $-0.034(-5.40)$ & $-1.595(-174.5)$ & $-3.913(-22.79)$ & $0.654(288.3)$ & 1.779 (41.98) & $-0.705(-911.1)$ & $-0.366(-68.19)$ & .40 & 1.90 \\
\hline
\end{tabular}

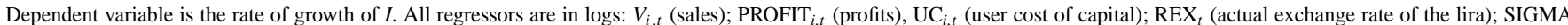
(standard deviation of REX). The actual estimation period is 1990-1994, due to the lags and first differences in the variables.

a GLS estimation method for 6 years. Student's $t$ is reported within the parenthesis. 
Table 4

Estimates of the dynamic investment model (ECM) with exchange rate variability and interaction with market power

\begin{tabular}{|c|c|c|c|c|c|c|c|c|c|c|c|c|c|c|c|}
\hline \multicolumn{16}{|c|}{ Whole sample (2988 firms) and Pavitt groups - (1989-1994) ${ }^{\mathrm{a}}$} \\
\hline & INTP & $\Delta V$ & $\Delta \mathrm{UC}$ & $\triangle \mathrm{REX}$ & $\mathrm{REX}_{t-1}$ & $V_{t-1}$ & $I_{t-1}$ & SIGMA. $\phi$ & SIGMA. $\delta$ & $\begin{array}{l}\text { Slope } \\
\text { dummy } \\
\text { SIGMA. } \phi\end{array}$ & $\begin{array}{l}\text { Slope } \\
\text { dummy } \\
\text { SIGMA. } \delta\end{array}$ & $\begin{array}{l}\text { Dummy } \\
\text { high } \\
\text { markup }\end{array}$ & $\begin{array}{l}\text { Dummy } \\
\text { low } \\
\text { markup }\end{array}$ & Adj. $R^{2}$ & DW \\
\hline Pavitt 1 & -3.44 & 1.22 & -2.08 & -1.17 & 2.43 & 0.74 & -0.76 & -0.15 & -0.08 & - & - & - & - & .44 & 2.04 \\
\hline High markup & -3.13 & 1.12 & -1.98 & 0.76 & 2.03 & 0.75 & -0.77 & - & - & -0.14 & -0.06 & $-0.003^{b}$ & - & .44 & 2.07 \\
\hline Low markup & -2.82 & 1.24 & -2.01 & 0.72 & 2.57 & 0.73 & -0.77 & - & - & -0.12 & -0.08 & & -0.44 & .44 & 2.06 \\
\hline Pavitt 2 & -3.46 & 1.001 & -1.50 & -1.61 & 1.61 & 0.76 & -0.74 & -0.07 & -0.03 & - & - & - & - & .41 & 2.00 \\
\hline High markup & -3.29 & 1.05 & -1.54 & -1.10 & 2.09 & 0.76 & -0.75 & - & - & $-0.05^{\mathrm{b}}$ & $-0.03^{\mathrm{b}}$ & -0.12 & - & .41 & 1.99 \\
\hline Low markup & -3.34 & 0.96 & -1.47 & -0.86 & 1.74 & 0.77 & -0.76 & & & -0.05 & -0.03 & & $-0.06^{\mathrm{b}}$ & .41 & 1.97 \\
\hline Pavitt 3 & -2.38 & 0.83 & -0.78 & 0.92 & 1.00 & 0.69 & -0.79 & -0.06 & -0.05 & - & - & - & - & .42 & 1.55 \\
\hline High markup & -2.44 & 0.81 & -0.83 & 1.12 & 1.05 & 0.72 & -0.82 & - & - & -0.07 & -0.11 & $-0.04^{\mathrm{b}}$ & - & .42 & 1.50 \\
\hline Low markup & -2.00 & 0.83 & -0.79 & 2.27 & 1.16 & 0.70 & -0.82 & - & - & $-0.02^{\mathrm{b}}$ & $-0.01^{\mathrm{b}}$ & - & -0.14 & .41 & 1.53 \\
\hline Pavitt 4 & -6.00 & 2.19 & -2.65 & $1.23^{\mathrm{b}}$ & $2.03^{b}$ & 1.05 & -0.87 & $0.01^{\mathrm{b}}$ & $0.02^{\mathrm{b}}$ & - & - & - & - & .44 & 1.34 \\
\hline High markup & -6.16 & 2.42 & -2.65 & $0.79^{\mathrm{b}}$ & $2.14^{\mathrm{b}}$ & 1.03 & -0.85 & - & - & $-0.08^{\mathrm{b}}$ & 0.08 & $0.24^{\mathrm{b}}$ & - & .44 & 1.39 \\
\hline Low markup & -5.46 & 2.32 & -2.78 & $-0.53^{b}$ & $2.13^{\mathrm{b}}$ & 0.98 & -0.83 & - & - & $0.06^{\mathrm{b}}$ & $-0.14^{\mathrm{b}}$ & - & -0.22 & .44 & 1.39 \\
\hline
\end{tabular}

Dependent variable: rate of growth of $I$. All regressors are in logs: $V_{i, t}$ (sales); $\mathrm{UC}_{i, t}$ (user cost of capital); $\mathrm{REX}_{t}$ (actual exchange rate of the lira); SIGMA (standard deviation of REX); $\delta$ (foreign exposure of revenues); $\phi$ (foreign exposure of costs). The slope dummy is calculated multiplying the relevant dummy by SIGMA. Pavitt 1 : supplier-dominated sectors; Pavitt 2: the specialised suppliers sectors; Pavitt 3: the for the scale-intensive sectors; Pavitt 4: science-based sector. The threshold value for grouping according to high-low markup is 55\%. The actual estimation period is $1990-1994$, due to the lags and first differences in the variables.

a GLS estimation method for 6 years.

b Parameter not significant at 5\% level. 
Exchange rate volatility reduces investment especially via imported inputs, and this result is quite obvious, as foreign exposure of costs reduces profit (see Table 2). But why does exchange rate volatility negatively affects investment spending also via the revenue channel? One possible explanation is the existence of a signal extraction problem. A higher volatility of export revenues gives a more unpredictable flow of future profits and, for non-reversible decisions like investment, this additional source uncertainty may reduce the level of its spending.

Taking into account firms market power, it is possible to underline other differences in firm behaviour. In the second and third row of each Pavitt group, we display the estimation results using dummies for high and low market power respectively. The intercept dummy and the two slope dummies account for differences of the response of SIGMA that interact separately with each of the two foreign exposure terms.

The evidence puts forward the idea that the effect of variability on investment is strictly linked to monopoly power, but it depends on the kind of sector. For the supplier-dominated sector, high mark up firms are less sensitive to exchange rate variability than the average on the revenue side, while are more sensitive on the cost side. In the specialised suppliers sector, we found that firms with monopoly power are not sensitive to exchange rate volatility, while the opposite result is found in the scale-intensive sector, where low mark up firms do not seem to respond to volatility. This may be due to the fact that, in our sample, low mark up firms import less inputs and export more output than the sample average. Therefore, they are less sensitive to the cost side and, due to higher competitive international markets, they can count on a lower mark up.

On the basis of these results, we can conclude that stability of the exchange rate may have a positive effect on the investment. This seems particularly true for firms with greater monopoly power, that can rely on a less volatile stream of future profits, and can better evaluate the marginal benefit of an additional unit of capital. This results in lower constraints in the adjustment to the optimal level of investment.

\section{Policy implications}

The results presented above induce to conclude that as long as firms will perceive the adoption of a single currency as a structural change with permanent effects, they will try to adjust to this new equilibrium.

At industry level, labour intensive firms in traditional sectors, exporting mainly to Euroland, may now become less profitable. If growth is more linked to competitive cost advantage rather than to innovation and technology adoption, these firms may find optimal to set capacity outside the Euro area, like for example in Eastern Europe. The reasons are well known, and range from the saving of labour costs to the opportunity offered by a flexible exchange rate. This process will be even more evident in the mid-term, with an effect on the level and structure of investment in these sectors. On the contrary, firms whose growth depends heavily on technology 
adoption (e.g., high tech firms), may benefit from a stable currency, provided they are able to optimally match technology adoption with organisational and human capital improvements.

All this will have the following important policy implications at country level (not limited to Italy):

1. In the mid-term we could expect to see remarkable changes in the productive structure of a country, with sectoral reallocations among the different firm categories discussed in the empirical analysis.

2. The investment path of a nation can change altogether with the capital accumulation process. Although it is too early to verify empirically such changes, it is quite reasonable to expect a modification in the investment dynamics through an acceleration of the investment in goods with a high content of R\&D.

3. Remarkable modifications should also occur in the labour input. In fact, investment in new equipment with a high content of $R \& D$ could be associated with a different labour demand. This may further affect the level of unemployment in a country.

It is clear that the conclusions that derive from these policy implications will reveal true as long as the effects of the euro, as a strong currency, will be perceived as permanent. As of today, there are many reasons to think that this will happen. Firstly, it must be recognised that today Euroland represents a much more closed economy than before 1998: most of what was external trade (about 60\%) is now internal trade. Second, although the euro has devaluated with respect to the dollar in its first years of life, the most recent events indicate that the euro can soon become a reserve currency, in which international reserves can be held, and an "anchor" currency. In fact, many countries that do not belong to the European Monetary System have started pegging their currencies to the Euro and conduct their exchange rate policy accordingly.

\section{Concluding remarks}

The empirical literature on the link between investment and exchange rate is rather scarce, probably due to the difficulties in disentangling the various effects within this link. However, such an exercise is extremely useful both at microeconomic level, to understand the effects on firm growth, and at macroeconomic level, to understand the transmission effects of monetary policies.

In Atella et al. (2003), the estimates from a dynamic ECM model show the existence of a positive long run elasticity between investment and exchange rate. This means that a devaluation does not support investment spending as previously stated by Campa and Goldberg (1999). Though in the short run profits may benefit from it, this does not imply firm growth in the long run. 
In our approach the key argument is the link exchange rate volatility-uncertainty. Even though a stable exchange rate does not allow for temporary gains following a devaluation, it eliminates a great source of uncertainty in the economic system. Profit expectations can be better evaluated by both firms and the financial system, resulting in higher confidence on investment profitability. This has been verified by employing a dynamic model which takes into account profit expectations. Our results show exchange rate volatility may exacerbate that of profits, because of signal extraction problems, which in turn reduce firms forecast ability and investment spending. The decrease in investment spending is inversely proportional to firm market power.

Another important result emerging from the empirical analysis is the importance of the two channels (revenues and costs) through which exchange rate affects investment. A devaluation may increase investment provided that the effect on costs is lower than that on revenues. This depends on the degree of firm foreign exposure and on other firm characteristics, such as its sector. According to our hypothesis, a volatile exchange rate reduces investment because it raises the difficulties related to the evaluation of marginal benefits of new capital goods. However, firms with high market power are shown to be more sheltered with respect to this problem.

To this extent, an economic system may benefit from a stable exchange rate in terms of investment and profit, provided it is able to strengthen its firm market power.

\section{Appendix A. Data sources and variables description}

\section{A.1. Data set}

The data set employed in this paper is collected by Mediocredito Centrale. The Survey of Manufacturing Firms (SMF) is carried on by the observatory on small and medium firms, which is within the Research Department of the Mediocredito Centrale. The survey was put in place for the first time in 1968, and then repeated more or less every 5 years until 1989. From 1989, the interval has been reduced to 3 years. The last three versions cover the periods 1989-1991, 1992-1994 and 1995-1997. The SFM samples firms with 11-500 employees and collects information on all the firms with more than 500 employees. The sample, of about 5000 firms, has been stratified according to the number of employees and location, taking as benchmark the Census of Italian Firms.

We employ two surveys covering a period of 6 years (1989-1994), with 2988 firms. The choice of period is particularly interesting because it comprises a period of wide exchange rate variability, due to the exit of lira from SME.

\section{A.2. Firm variables}

Profits are calculated as the ratio of the difference between value added and labour costs and sales: PROFIT $=($ value added - labour costs $) /$ sales. 
The user cost of capital is given by the usual formula: $\mathrm{UC}_{i}=P_{i}\left(r_{i}+\operatorname{dep}_{i}+\right.$ $\left.\Delta P_{i, t} / P_{i, t}\right)$, where $P_{i}$ is the deflator for new capital goods; dep is depreciation of installed physical capital, calculated with a moving average over three years of the ratio between depreciation and the book value of physical capital; $r$ is the average interest rate on debt, calculated with a moving average over 3 years of the ratio between total interest paid and the sum of short and long-term debts.

Mark-up: mkup $=1-[$ (sales $+\Delta$ inventories - intermediate inputs $) /($ sales + $\Delta$ inventories)]. The threshold value for high and low markup firms is set at 55\% which corresponds to average value.

\section{A.3. Foreign exposure of cost and revenues}

By this term we denote the degree of firm dependence respectively on import of inputs and export sales. This latter value is reported in the survey. The foreign exposure of cost is proxied by the ratio between debt with foreign suppliers and debt with all suppliers. If firms keep a stable relationship with non-domestic suppliers, this measure is likely to be unbiased.

Foreign exposure of revenues: $\delta=$ export/sales.

Foreign exposure of costs: $\phi=$ debt with foreign supliers/debt with all supliers

\section{A.4. Macroeconomic variables}

\section{A.4.1. Exchange rate}

$R E X$ is the actual real exchange rate as calculated by Bank of Italy. This is the price of a bundle of foreign currencies expressed in terms of liras. Therefore, a reduction of exchange rate means a devaluation of lira with respect to the currencies in the bundle. The rate of growth is obtained by $\left(\mathrm{rex}_{t}-\mathrm{rex}_{t-1}\right) / \mathrm{rex}_{t}$. The exchange rate variability is calculated as the annual average standard deviation of quarterly $R E X$.

\section{A.4.2. Deflators}

Sales are deflated employing GDP deflators. Investment is deflated using the investment deflator (Source: Banca d'Italia).

\section{Appendix B. The impact of exchange rate variability on profit}

The exchange rate-profit relationship may be estimated by OLS employing the following equation:

$$
\text { PROFIT }_{i, t}=\beta_{0} \text { PROFIT }_{i, t-1}+\beta_{1} \text { rex }_{t-1}+\beta_{2} \text { SIGMA }_{t-1}
$$

where SIGMA denotes exchange rate variability. ${ }^{7}$ In order to verify the impact through the costs and revenues channels, we split exchange rate variability

\footnotetext{
${ }^{7}$ See Appendix A for the details about the calculation of variables.
} 
according to foreign exposure of costs $(\phi)$ and revenues $(\delta)$ :

$$
\begin{aligned}
\operatorname{PROFIT}_{i, t}= & \beta_{0} \text { PROFIT }_{i, t-1}+\beta_{1} \operatorname{rex}_{t-1}+\beta_{2}\left(\delta_{i} \operatorname{SIGMA}_{t-1}\right) \\
& +\beta_{3}\left(\phi_{i} \text { SIGMA }_{t-1}\right)
\end{aligned}
$$

The results are reported in Table 4. In the first row the estimate of parameters of Eq. (B.1) are displayed. A devaluation in the previous period increases profit, but exchange rate variability, represented by SIGMA, reduces firm profitability. ${ }^{8}$ In the second row we show the results of the estimation of Eq. (B.2), with SIGMA split. We found evidence for the theoretical hypothesis that while an increment of volatility may reduce profit through the cost channel, it may increase them through that of revenues, because a greater variability is associated to higher profit opportunities. This finding can be strengthened if we take into account firm market power. In the last two rows of Table 4 we estimate Eq. (B.2) introducing a dummy for mark up. Firms with higher market power are not sensitive to exchange rate volatility through the cost channel, as they can offset a rise in the cost of imported inputs with higher mark ups. On the contrary, firms with less market power seem able to profit from exchange rate variability.

\section{References}

Atella, V., Atzeni, G. E., \& Belvisi, P. (2003). Will the euro be beneficial on firm's investment behaviour? An empirical investigation on a panel of Italian firms. CEIS Working Paper, No. 180.

Campa, J., \& Goldberg, L. (1995). Investment, exchange rates and external exposure. Journal of International Economics, 38, 297-320.

Campa, J., \& Goldberg, L. (1999). Investment, pass-through and exchange rates: A cross-country comparison. International Economic Review, 40, 287-314.

Darby, J., Hallet, A. H., Ireland, J., \& Piscitelli, L. (1999). The impact of exchange rate uncertainty on the level of investment. The Economic Journal, 109, 55-67.

Dixit, A., \& Pindyck, R. (1994). Investment under uncertainty. Princeton, NJ: Princeton University Press.

Goldberg, L. (1993). Exchange rate and investment in United States industry. Review of Economics and Statistics, 75, 575-588.

Goldberg, L., \& Tracy, J. (1999). Exchange rates and local labour markets. Federal Reserve Bank of New York, Staff Report No. 63.

Hayashi, F. (1982). Tobin's marginal $q$ and average $q$ : A neoclassical interpretation. Econometrica, 50, 213-224.

Lucas, R. (1973). Some international evidence on output-inflation trade offs. American Economic Review, 63, 326-334.

Nucci, F., \& Pozzolo, A. F. (2001). Investment and the exchange rate: An analysis with firm-level panel data. European Economic Review, 45, 259-283.

Onida, F. (1986). Tassi di cambio, vantaggi comparati e struttura industriale. In T. Padoa Schioppa (Ed.), Il sistema dei cambi oggi. Il Mulino: Bologna.

Paganetto, L. (1995). Tassi di cambio, investimenti e sistema industriale italiano. In Studi per il Cinquantenario (pp. 85-111). Bari-Roma, Laterza: Ufficio Italiano Cambi.

${ }^{8}$ The test on the restriction on the parameters $\beta_{2}=\beta_{3}=0$ in Eq. (B.2) shows the importance of SIGMA in the profit function. 